\title{
Metaphorical Use of Algorithm in Legal Reasoning
}

\author{
Alessandro Campo ${ }^{1}$ (1) \\ Accepted: 11 September 2020 / Published online: 19 September 2020 \\ () The Author(s) 2020
}

\begin{abstract}
The current use of big data in the legal framework suggests the idea of algorithm as a new topos of the legal rhetoric. Indeed, in addition to the "rhetoric of algorithm", an "algorithm of rhetoric" may also exist, in strict connection with an anthropological structure. Even leaving aside its epistemic value, the algorithm is in fact always experienced by the jurist through a metaphorical process, in a very similar way, for instance, to the metaphorical use of graphs in economics (McCloskey). That said, the reasoning about big data is metaphorical as well, and this allows us to believe that there is still a role for pathos and ethos within the legal reasoning. Moreover, and most importantly, the ideal to which the data-based knowledge (the so called dataism) aims - that is, the pretension of being able to map all that there is to know-is metaphorical, too. In this paper I will discuss algorithms and big data in the guise of new topoi. The aim of this paper is therefore to imagine a philosophical-juridical semiotic by means of which it is possible to highlight the persistent difference between reasonableness and reason in the judge's work. Vis-à-vis algorithms and big data, as well as the rules of law, the judge does not act as bouche de la loi, but rather practices a reason which is irreducibly rhetoric and related to the humanities.
\end{abstract}

Keywords Algorithms $\cdot$ Metaphor $\cdot$ Humanities $\cdot$ Reasonableness

Alessandro Campo

alecampo1988@gmail.com

1 Università del Piemonte Orientale, Corso Sebastopoli 39, 10134 Turin, Italy 


\section{Law as Humanities}

Wil our next lawyer be a machine? ${ }^{1}$

I think that if he were a robot, everything would change.

If on the contrary the lawyer is the old homo sapiens sapiens, he will still have to deal with rhetoric, ${ }^{2}$ interpretation, humanistic disciplines and the classical epistemological problems of law.

I conceive the humanistic disciplines, in a way, as a necessary foothold for reason (and for legal reason as well), without this having to involve any irrationalism. Therefore, the very first question of method that arises is openly anti-Cartesian. The method used here for approaching law is based on an idea of Law as humanities and not simply of Law and humanities. As far as the Law and humanities approach is concerned, I would only note that there is already an extensive literature on the subject, to which I simply refer to [17, 21, 29, 30, 33] as there would be no reason to dwell on it. Heritier's idea-and not just his-is that the so-called humanities are an integral part of the legal discourse [19, 20].

According to this approach, if the sapiens facing law has to deal with humanities, he has to deal with humanities also while facing algorithms, unless he starts to imitate the machine and become another kind of interpreter. As a consequence, the jurist needs to use humanities facing the strict connection between law and algorithms.

The sapiens, in other words, will have to deal with humanistic disciplines unless he starts a different interpretation, just as the machines will eventually produce another art thanks to machine learning. As Gabriele Marino pointed out in the IRSL roundtable, ${ }^{3}$ machines are already able to replicate human art. Once we have established that, human beings' problem is still to understand any forms of expression different from their own (if it can be argued that the machines express themselves). The relationship between art and machines seems in fact to imply an ontological problem (do machines conceive autonomous art?) and an epistemological one (how does man understand said art?). ${ }^{4}$

\footnotetext{
1 This is the question that professor Leone asked at the beginning of his speech at the roundtable The reasonable interpreter, International Roundtables for the Semiotics of Law-IRSL, Torino, 19-20 September 2019: Facing Digital Reasonability. It is an important question because the positive answer would imply a general rethinking of the relationship between law and technology. I will try to answer this question by asking another question. The new question is perhaps why a man-judge cannot be a machinejudge.

2 The connection between rhetoric and law was highlighted in the 1900s by Perelman [35, 36], whose perspective was developed in Italy above all by Manzin [26] and Heritier [19], who refers to Vico. This paper welcomes a critical perspective of legal positivism and favors a close relationship between rhetoric and law.

${ }^{3}$ The reasonable interpreter, International Roundtables for the Semiotics of Law-IRSL, Torino, 19-20 September 2019: Automatic for the People. A Brief Cultural History of the Relation between Computation and So-Called Art.

${ }^{4}$ These questions recall the one of the successful book by Philip K. Dick Do Androids Dream of Electric Sheep? [11].
} 
Because human beings' approach to these problems is always the same, in my perspective the old sapiens sapiens (that is a rather arrogant name) will continue to be himself, and will face algorithms, big data and so on in his specific, human, all too human, way.

\section{Cultural Machines}

And he must admit that algorithms, which we made and continue to make, are located in cultural machines: "the algorithm, has its roots not only in mathematical logic but in the philosophical traditions of cybernetics, consciousness, and the magic of symbolic language. To understand the algorithm, we need to uncover those roots and then build a new model of "algorithmic reading" that incorporates a deep understanding of abstraction and process. The algorithm deploys concepts from the idealized space of computation in messy reality, implementing them in what I call "culture machines": complex assemblages of abstractions, processes, and people" $[15$, p. 2].

I would add that maybe the old sapiens is always present in cultural machines in the same way he is in mythological machines, the concept introduced by Furio Jesi ${ }^{5}$ [23]: we do not talk about myth from an external point of view, since we are always caught inside the (or in a) mythological machine. This thesis implies a theoretical claim according to which every philosophy should also be a mythophily. There is a phenomenological and anthropological point related to this epistemological issue, according to which everyone lives in a mythical way. And, moreover, to everyone is given the chance to try and report this experience of myth. This appears to be a significant aspect, at least from an anthropological-philosophical point of view and it becomes a question of method in the debate on algorithms.

If I had to express myself with a paradox, I would say that the sapiens live in a sort of original state of culture, because the cultural machine has always existed. In this unachievable state of culture, the metaphor is eventually the heart of a possible theoretical aconceptualism, in the meaning given by Blumenberg, who calls absolute metaphor the one which resists any attempt to be reduced to concept [3].

I could say that in some way the Hobbesian state of nature is original, but the state of culture is original as well, in a situation beyond nature and culture [8, 10, 25]. In any case this argument would involve dealing with a very complicated philosophical question: the issue of the limits of rationalism should be addressed and this is not the place to deal with this topic.

\footnotetext{
${ }^{5}$ When speaking about algorithms, we use many commonplace expressions which, according to Jesi, are in a certain sense similar to the myth: "Così come i miti, essi sono qualcosa di cui una esperienza creative insiste nel farci credere l'esistenza, tenendocene al tempo stesso celata l'essenza [...]. È qui in funzione una vera e propria macchina mitologica, la macchina mitologica, che produce mitologie e induce a credere, pressante, che essa stessa celi il mito entro le proprie pareti non penetrabili. Se i luoghi comuni posseggono esistenza ed essenze, autonome, essi provengono da "un altro mondo", poiché solo così possiamo designare un mondo che non è il nostro essendo abitato da loro a fianco a noi, autonomamente da noi, senza che in alcun modo interagiscano con noi: per toccarci devono giungere" [24, p. 27, 9].
} 


\section{Metaphors and Algorithms}

Facing this complex question, it is at least possible to affirm that there is an epistemological difficulty in defining the cultural machine and the mythological machine, ${ }^{6}$ because everyone is inside them. In a sense, we may always have the great humanistic problem of choosing the right metaphor ${ }^{7}$ and the underlying epistemological question sounds like this: "Which came first: the concept or the metaphor?".

Before continuing with the reasoning, it is useful to quote Finn once again: "When technologists, researchers, and entrepreneurs speak about computational culture today, this deep myth of the algorithm is typically obscured by layers of rationalizing rhetoric and the procedural metaphors of software design. Indeed, the most prevalent set of metaphors seems to be that of code as structure: platforms, architectures, objects, portals, gateways" [15, p. 6].

So, staying in our mythological or cultural machines, we deal with metaphors to understand algorithms (just as, in the field of economics, we need rhetoric, metaphors and so on to understand the concepts, according to the economist Deirdre Mccloskey [28]. We could argue that if the economist needs rhetoric, using graphs, abscissas, ordinates and other signs, the contemporary academician needs rhetoric too, because he uses slides and so on.)

Even though the argument that each concept is only an expedient (Paul Valery's thesis [37]) is hyperbolic, there is still something, perhaps what Blumenberg ${ }^{8}$ calls absolute metaphor, which cannot be reduced to concept. The claim here is that we have to manage this "something" while we are thinking about algorithms.

\footnotetext{
${ }^{6}$ Surely there is a theoretical problem, but, above all, there is the problem of defining something in which we are.

7 Another question that should be explored is the following: is it possible to invent new metaphors?

8 "Metaphors are unable to satisfy the requirement that truth, by definition, is the result of a methodologically secure procedure of verification. They therefore not only fail to say 'nothing but the truth', they do not say anything truthful at all. Absolute metaphors 'answer' the supposedly naïve, in principle unanswerable questions whose relevance lies quite simply in the fact that they cannot be brushed aside, since we do not pose them ourselves but find them already posed in the grounds of our existence. We must bear in mind here that a metaphorology cannot result in any method for using metaphors, or for addressing the questions that announce themselves in them. On the contrary: as students of metaphorology, we have already deprived ourselves of the possibility of finding 'answers' in metaphors to those unanswerable questions. Metaphor, as the theme of a metaphorology in the sense that will concern us here, is an essentially historical object whose testimonial value presupposes that the witnesses did not possess, and could not have possessed, a metaphorology of their own". [3, p. 28].
} 


\section{Algorithms and Literature}

The human being speaks of rationality (the place of concept) starting from irrationality and vice versa: this fact is shown by great literature such as that of Shakespeare. ${ }^{9}$ Perhaps it is necessary to try to go beyond the rigid border between reason and unreason, or maybe to reason and unreason taking turns with both.

Indeed, according to Donà [13], the tragedy of King Lear shows this issue from a philosophical point of view. Literature is maybe the place in which we could go beyond the border between reason and unreason: in this sense it is useful when we talk about algorithms, as we'll see.

Consequently, even if we are inside a heap of nature and culture, there is maybe a heuristic sense to imagining a sort of critical humanism or a sort of critical anthropocentrism. ${ }^{10}$

In this sense we can at best aspire to a Deleuzian becoming-machine [9], but we can never speak as if we were machines (in the same way we can't speak as if we were animals, plants or things ${ }^{11}$ ). In other words, even if we let the animal [5], the plant [7], or the thing [6] do the talking, we still must use our expressiveness and, in philosophy, we must use the concept. When we are talking about the Other from us, even in philosophy we inevitably end up using the literary register. If conceptual language is not enough to talk about something which is non-conceptual (e.g. impersonal life, animal, plants, things), then philosophy turns to literature, concept turns to metaphor.

On the other hand, though, I argue that while algorithm is (in) a cultural machine, the human factor is deep inside the algorithm.

According to Edd Finn, "[...] the datasets are mined by scoring systems; they define the parameters of data-mining analyses; they create the clusters, links, and decision trees applied; they generate the predictive models applied. Human biases and values are embedded into each and every step of development. Computerization may simply drive discrimination upstream" [15, p. 21].

\footnotetext{
${ }^{9}$ Bloom says "The answer to the question "Why Shakespeare?" must be "Who else is there?" [2, p. 1] "A venire disegnata, in questa grande tragedia della maturità, è nientemeno che la struttura aporetica del fondamento, ossia l'articolazione di un principio originariamente implicante la radicale impossibilità di distinguere "ragione" e follia; di contro a quanto si sarebbe ritenuto di poter e dover fare, da parte di un pensiero costantemente ossessionato dal bisogno di distinguere innanzitutto la verità dall'errore" [13, p. $33,16]$.

10 "Paradossalmente la soluzione non va cercata e trovata fuori, oltre l'umanismo stesso, ma va cercata e trovata elaborando e praticando un nuovo umanismo" [34, p. 198].

${ }^{11}$ This may be the risk of those who criticize anthropocentrism. I suggest that one should not run into anthropocentric hubrs even insisting on the paradox of denying human specificity [5, 7].
} 


\section{Machines' Imagination}

In any case, one always remains in the field of human belief: "We believe in the power of code as a set of magical symbols linking the invisible and visible, echoing our long cultural tradition of logos, or language as an underlying system of order and reason, and its power as a kind of sorcery. We believe in the elegant abstractions of cybernetics and, ultimately, the computational universe - that algorithms embody and reproduce the mathematical substrate of reality in culturally readable ways" $[15$, p. 34]. The consequence of this belief is mythopoesis: "This is what it means to say that an algorithm is a culture machine: it operates both within and beyond the reflexive barrier of effective computability, producing culture at a macro-social level at the same time as it produces cultural objects, processes" [15, p. 34].

Maybe here the anthropological relevance of this belief is the central point: we are curious about algorithms, but we try to understand them in a human way (and of course there is no possible machine learning for us).

The dizziness determined by our epistemological gap is also interesting: "Aside from the most simplistic cases, we will never know how algorithms know what they know. This is the computational space of imagination, or what in $\mathrm{Her}^{12}$ Samantha calls the "space between the words" [15, p. 185] and once more shows the necessity of humanities. The author needs the language of art, needs the movie Her, to imagine what the machine's imagination is.

To imagine machines' imagination is not easy. I think this is precisely the problem of overcoming anthropocentrism: it is quite impossible to imagine what a plant, an object or a machine thinks. If conceptual language is not enough to talk about something which is non-conceptual (e.g. impersonal life, animal, plants, things, algorithms), then, as I've said, philosophy turns to literature.

From our human point of view "We can choose to construe the figure of the algorithm as a god to be worshipped [...] or we can choose to see a new player, collaborator, and interlocutor in our cultural games". [15, p. 192]. In any case, we must answer the question about the kind of interlocutor and somehow, we are imaging the interlocutors all the time [2, 5-7]).

This is the main point: even if we know that we are dealing with cultural machines, we can't know what kind of metaphors, rhetoric, and figures of speech our biochemical algorithm has inside. ${ }^{13}$ In other words, whatever the nature of the algorithm we have inside, we must make an act of faith towards the cognitive rationality of the algorithm. This seems to me the anthropological issue of human complexity facing the algorithm. The fact that faith is always associated with rationality is a consequence of this complexity (complexity which is guarded by literature and philosophy).

\footnotetext{
${ }^{12} \mathrm{Her}$ is a 2013 American science-fiction romantic drama film written, directed, and produced by Spike Jonze.

13 The almost mythical insistence on a determinism deriving from biochemical algorithms is expressed in Harari's texts, which are an excellent example of powerful historical and scientific dissemination [18].
} 
This complexity is also why I think it is useful to maintain, from a theoretical point of view, a minimal anthropocentrism. In a sense, anti-anthropocentrism wants from man more than man can do, both in epistemological and ontological terms: it risks being, because of his prometheism, paradoxically more anthropocentric than anthropocentrism in itself.

The suggestion is therefore to live critically the mythology of the algorithm. We maybe need a mythology that includes mythos and $\log { }^{14}{ }^{14}$; we need a mythology that contains in itself both belief (like Lear says "We'll think about the mysteries of the universe as if we were God's spies") and criticism.

\section{Romantic-Algorithmic Lie and Romanesque Truth}

Furthermore, we must prevent computationalism from becoming a new conceptism; paraphrasing Girard [16], we have to think about the links between romantic-algorithmic lie and Romanesque truth. Speaking about the necessary kinship between philosophy and literature, it's useful to quote now the novelist Ian McEwan [27] and his recent book about robots Machines like me: "When the marriage of men and women to machines is complete, this literature will be redundant because we'll understand each other too well [...] Our narratives will no longer record endless misunderstanding. Our literatures will lose their unwholesome nourishment. The lapidary haiku, the still, clear perception of things as they are, will be the only necessary form". We could add that until that moment we will still use literature to understand something about machines. I would also add that until that moment we need humanities in general, we need McEwan (and Ed Finn needs movies) to understand the 'other' which the machine is, beyond Plato's palaia diaphorà between philosophy and art or beyond the idea that lies belong to romance (16).

\footnotetext{
14 "Si può dunque concludere con discreto fondamento che il sostantivo mythologia e il verbo mythologeuo accolsero e conservarono un significato restrittivo dell'originaria parola mythos: il significato di "parola efficace" ridotta a "narrazione non obbligatoria, non implicante argomentazioni"; mentre il significato di mythos come "parola efficace", "progetto", "macchinazione", "deliberazione", si trasferì quasi esclusivamente nella parola logos e sopravvisse nel verbo mythiazomai. Questo vuol dire che la congiunzione di mythos e logos (mythologia, mythologeuo) corrispose alla svalutazione di mythos come "parola efficace", a vantaggio di $\log o s ;[\ldots]$ E dunque ciò induce a supporre che nella storia della lingua greca dopo Omero si sia progressivamente attuata-già prima di Protagora-una svalutazione di mythos a favore di logos, tanto che le commistioni di mythos e logos furono restrizioni del significato di mythos, quasi che mythos, al contatto diretto con il suo concorrente (non ancora con il suo "contrario"), logos, fosse destinato a cedere parte di sé. Ciò è particolarmente importante, poiché fornisce una base filologica all'ipotesi che la parola mythos significasse originariamente anche l'essenza dei racconti intorno a "dèi, esseri divini, ecc.", e che proprio questa essenza da un lato abbia determinato con la sua crisi la svalutazione e la restrizione semantica di mythos, d'altro lato sia sopravvissuta nell'oggetto indicato dal vocabolo caratteristico dell'istante di crisi: mythologia” [22, pp. 20-21].
} 


\section{Algorithms and Rhetoric}

In any case we use rhetoric all the time while we imagine the machines or the algorithms. For instance, Pedro Domingos [12], in another successful book, tries to imagine something which he calls master algorithm "Thanks to the master algorithms all present, past and future knowledge can be derived from a single universal learning algorithm. I decided to call it the master algorithm". Isn't this the choice of a rhetorical figure (the master algorithm), powerful and suggestive (as, speaking about topoi and algorithms, the black box is a rhetorical figure)?

Looking at these numerous and fascinating rhetorical figures, I start to think that we are in the age of "Myth of the algorithm". We live in the time of myth of algorithm and, at the same time, we have deep inside an algorithm of myth and metaphor, although we don't know where its' pineal gland is (which is a sort of a master biochemical algorithm, another metaphor indeed).

In this specific age we may have specific problems. Thinking about law, the main question is probably the one of algorithmic legitimacy. We move from the community's legitimacy to the algorithms' legitimacy, by breathing the ideology of dataism $[18,31]$. We need to underline that, as I've argued, each algorithm is a matter of literature (thinking about Asimov and McEwan, but also Shakespeare: our biochemical algorithms are in some way such stuff as literature is made of), because otherwise, from a legal point of view, the algorithm takes the positivistic place of the norm as a result.

If we think back to the question at the beginning of the article and reflect again on the sapiens as an interpreter, we may have to consider the algorithm as a topos in lawyers' rhetoric and prevent dataism from becoming a new kind of normativism.

\section{The Question of the Map}

On the contrary, in this age of "Myth of the algorithm", we'll start to think that algorithms and data can describe the entire word like the Empire's map [4].

As Borges writes "In that Empire, the Art of Cartography attained such Perfection that the map of a single Province occupied the entirety of a City, and the map of the Empire, the entirety of a Province. In time, those Unconscionable Maps no longer satisfied, and the Cartographers Guilds struck a Map of the Empire whose size was that of the Empire, and which coincided point for point with it. The following Generations, who were not so fond of the Study of Cartography as their Forebears had been, saw that that vast map was Useless, and not without some Pitilessness was it, that they delivered it up to the Inclemencies of Sun and Winters. In the Deserts of the West, still today, there are Tattered Ruins of that Map, inhabited by Animals and Beggars; in all the Land there is no other Relic of the Disciplines of Geography". The uselessness of this kind of map, which is underlined from Umberto Eco, in his short story "On the Impossibility of Drawing a Map of the Empire on a Scale of 1 to 1". [14], is a possible risk of dataism. 
For example we take this risk about The Compas Program.

Compas, an acronym for Correctional Offender Management Profiling for Alternative Sanctions, is a case management and decision support tool developed and owned by Northpointe (now Equivant) used by U.S. courts to assess the likelihood of a defendant becoming a recidivist.

Thinking to dataism, we probably have to be careful and avoid considering this program as something that can describe everything in an objective way. The use of Compas is surely interesting, but we also have to think about the consequences of its use and especially about the ideological consequences.

Lawyers are often fascinated by the idea of all-inclusive knowledge. According to this claim, we could say that the Napoleonic Code, ideologically speaking, was a sort of Borges' map (speaking about this ideological risk in other disciplines, we could mention DSM in psychiatry and, in human rights' theories, even Nussbaum's list of capabilities [32]).

Keeping in mind the lawyers' fascination we could also say something from the point of view of the general theory of law. If the crisis of the sources of law is fullblown [1], maybe it is possible that effectiveness takes the place of validity. In this sense the emergence of techniques which can measure everything clearly gives a new strength to the concept of effectiveness.

Because of this new strength this "theory of everything" could shift from the plane of having to be to the plane of being. The problem arising (the one of Borges' map) is however the same and one could say with a slogan and a little joking that lawyers will move "from Kelsen to Compas".

I think that the lawyer has to know that algorithms, data and so on are rhetorical issues in the same way that norms are. As a result, the lawyer must recognize that there is still a role for pathos and ethos within the legal reasoning and, from another point of view, he must know that a difference still exists between reasonableness and reason in judges' work [26]. The lawyer, according to this perspective, also needs to know that the very successful old idea of sources of law is a metaphor and it is not an all-inclusive map.

In conclusion we could say that for the jurist machine learning is important but metaphor learning is important as well.

Funding Open access funding provided by Università degli Studi di Torino within the CRUI-CARE Agreement.

Open Access This article is licensed under a Creative Commons Attribution 4.0 International License, which permits use, sharing, adaptation, distribution and reproduction in any medium or format, as long as you give appropriate credit to the original author(s) and the source, provide a link to the Creative Commons licence, and indicate if changes were made. The images or other third party material in this article are included in the article's Creative Commons licence, unless indicated otherwise in a credit line to the material. If material is not included in the article's Creative Commons licence and your intended use is not permitted by statutory regulation or exceeds the permitted use, you will need to obtain permission directly from the copyright holder. To view a copy of this licence, visit http://creativecommons.org/licen ses/by/4.0/. 


\section{References}

1. Andronico, Alberto. 2012. Viaggio al termine del diritto. Saggio sulla governance. Torino: Giappichelli.

2. Bloom, Harold. 1998. Shakespeare: The Invention of the Human. New York: Riverhead Books.

3. Hans, Blumenberg. 1969. Paradigms for a Metaphorology. New York: Cornell University Press.

4. Borges, Jorge Luis. 1961. Del rigore della scienza in Storia universale dell'infamia. Milano: Il Saggiatore.

5. Caffo, Leonardo. 2020. Il cane e il filosofo. Lezioni di vita dal mondo animale. Milano: Mondadori.

6. Cimatti, Felice. 2018. Cose. Per una filosofia del reale. Torino: Bollati Boringhieri.

7. Coccia, Emanuele. 2016. La vie des plantes. Une métaphisique du mélange. Paris: Bibliothèque Rivages.

8. Castro, De, and Eduardo Viveiros. 2009. Métaphysiques cannibales: Lignes d'anthropologie poststructurale. Paris: PUF.

9. Deleuze, Gilles, and Felix Guattari. 1980. Mille plateaux. Capitalisme et schizofrénie. Paris: Les Éditions de Minuit.

10. Descola, Philippe. 2006. Par-delà nature et culture. Paris: Gallimard.

11. Dick, Philip K. 1968. Do Androids Dream of Electric Sheep?. New York: Doubleday.

12. Domingos, Pedro. 2015. The Master Algorithm. New York: Basic Books.

13. Donà, Massimo. 2016. Tutto per nulla.: La filosofia di William Shakespeare. Milano: Bompiani.

14. Eco, Umberto. 1992. Dell'impossibilità di costruire la Carta dell'Impero 1 a 1 in Secondo Diario Minimo. Milano: Bompiani.

15. Finn, Ed (ed.). 2017. What Algorithms Want: Imagination in the Age of Computing. Cambridge: MIT Press.

16. Girard, René. 1965. Menzogna romantica e verità romanzesca. Milano: Bompiani.

17. Goodrich, Peter. 2013. Legal Emblems and the Art of Law: Obiter Depicta as the Vision of Governance. New York: Cambridge University Press.

18. Harari, Yuval Noah. 2016. Homo Deus: A Brief History of Tomorrow. London: Harvill Secker.

19. Heritier, Paolo. 2012. Estetica giuridica Vol. 1 e 2. Torino: Giappichelli.

20. Heritier, Paolo. 2016. Nodi nelle Law and Humanities: Vico, Joyce, Lacan. TCRS La Legge di Lacan. Psicoanalisi e Teoria del diritto 2: 139-161.

21. Holson, Greta. 2015. Futures of Law and Literature. A Preliminary Overview from a Culturalist Perspective. Law and Literature In-Between: Contemporary Inter- and Transdisciplinary Approaches, 37-69.

22. Jesi, Furio. 1989. Il mito. Milano: Mondadori.

23. Jesi, Furio. 1977. La festa. Etnologia, antropologia, folklore. Torino: Rosenberg \& Sellier.

24. Jesi, Furio. 1972. Lettura del Bateau Ivre di Rimbaud. Macerata: Quodlibet.

25. Latour, Bruno. 1991. Nous n'avons jamais été modernes. Essai d'anthropologie symétrique. Paris: La Découverte.

26. Manzin, Maurizio. 2012. Argomentazione giuridica e retorica forense. Dieci riletture sul ragionamento processuale. Torino: Giappichelli.

27. McEwan, Ian. 2019. Machines like me and people like you. London: Jonathan Cape.

28. McCloskey, Deirdre. 1985. The Rhetoric of Economics. Madison: University of Wisconsin Press.

29. Minda, Gary. 1995. Postmodern Legal Movements. Law and Jurisprudence at Century's End. New York: New York University Press.

30. Mittica, Maria Paola. 2012. The Heart of Law. No Foundations: An Interdisciplinary Journal of Law and Justice, Special Number on Law's Justice. A Law and Humanities Perspective 9: 97-118.

31. Monahan, Torin. 2018. Algorithmic Fetishism. Surveillance \& Society 16: 1-5. https://doi. org/10.24908/ss.v16i1.10827.

32. Nussbaum, Martha. 1999. Women and Human Development: The Capabilities Approach. Cambridge: Cambridge University Press.

33. Ost, François. 2004. Raconter la loi. Aux sources de l'imaginaire juridique. Paris: Odile Jacob.

34. Pasqualotto, Giangiorgio. 2018. Umanismo in Alfabeto Filosofico, 193-199. Venezia: Marsilio.

35. Perelman, Chaïm. 1976. Logique Juridique. Paris: Dalloz.

36. Perelman, Chaïm, and Lucie Olbrechts-Tyteca. 1958. Traité de l'argumentation: La nouvelle rhétorique. Paris: Presses Universitaires de France.

37. Valery, Paul. 1933. L'Idée fixe ou Deux hommes à la mer. Paris: Gallimard. 
Publisher's Note Springer Nature remains neutral with regard to jurisdictional claims in published maps and institutional affiliations. 